\title{
Evaluation of the current state of small pelagic fisheries in the Colombian Pacific: ensuring the sustainability of the resource and evaluating its response to climatic events
}

\author{
L. A. Zapata ${ }^{1}$, B. S. Beltrán-León ${ }^{1,2}$, J. C. Herrera ${ }^{1}$, P. Jiménez-Tello ${ }^{1,3}$, L. M. Prieto ${ }^{1,3}$, R. A. Baos ${ }^{1}$, \\ C. Guevara-Fletcher ${ }^{4}$, and E. Zambrano ${ }^{5}$ \\ ${ }^{1}$ WWF, Cali, Colombia \\ ${ }^{2}$ National Natural Parks, DTPA, Cali, Colombia \\ ${ }^{3}$ Universidad del Valle, Cali, Colombia \\ ${ }^{4}$ Incoder, Cali, Colombia \\ ${ }^{5}$ HARIMAR S. A., Buenaventura, Colombia \\ Correspondence to: L. A. Zapata (lazapata@wwf.org.co)
}

Received: 18 May 2011 - Revised: 18 May 2011 - Accepted: 1 October 2012 - Published: 2 April 2013

\begin{abstract}
Commercial fishing of small pelagic species in Colombia, mainly "carduma" (Cetengraulis mysticetus) and "plumuda" (Opisthonema spp.), has been recorded since 1970. Both are used to produce fish meal for aquaculture and poultry and for canned foods. These two species are filter feeders, and therefore support higher levels of the food chain (other fish, birds and marine mammals), and artisanal fishermen use them as bait. Between 2005 and 2010, 86.131 t have been captured $\left(\bar{X}=14.355 \mathrm{tyr}^{-1}\right)$, and a strong reduction was noticed in $2009(6.969 \mathrm{t})$. Carduma is considered a total spawning species. However, from 1997 to 2000 and from 2008 to date, atypical reproductive behavior of the species has been observed, including partition of the spawning period and the reduction of the volume of eggs and larvae released to the environment. Both situations are linked to thermal anomalies such as El Niño and La Niña events. Therefore, the process of assigning the global quota of extraction has been revised to take into account the reduction of total capture during the last years and the inconsistencies of the reproductive processes. The Ministry of Agriculture reduced the quota by $10 \%$, leaving available a total of $27000 \mathrm{t}$ for 2010 and reduced it again to $25000 \mathrm{t}$ for 2011 . It is important to maintain the management measures that are already implemented on this resource (bans during reproduction seasons, catch quotas, regulation of mesh sizes for the fishing nets, and limiting the number of new vessels) and considering other measures such as season closure for recruitment
\end{abstract}

and establishment of marine protected areas to further contribute to the sustainability of these fisheries.

\section{Introduction}

Small pelagic fisheries in the Colombian Pacific date back to 1950-1960, when these resources were used as bait in large tuna vessels that passed through the area. Beginning in 1970 , catches were used by the fish meal industry to produce food for poultry (Zapata et al., 2007). The principal species of this small pelagic fishery are "carduma" Cetengraulis mysticetus (Gunther, 1866) and "plumuda" Opisthonema spp. (Gill, 1861). Other less important species include Anchovia macrolepidota (Kner, 1863), Anchoa nasus (Kner and Steindachner, 1867) and Anchoa spinifer (Valenciennes, 1848) (family Engraulidae), as well as Ilisha furthii (Steindachner, 1875) and Lile stolifera (Jordan and Gilbert, 1882) from Clupeidae, and Chloroscombrus orqueta (Jordan and Gilbert, 1883) and Selene spp. (Lacépède, 1803) (family Carangidae). All these species are used for human consumption, as bait, or as fish meal.

Cetengraulis mysticetus is the second most important fishery resource of the Colombian Pacific, contributing $27 \%$ of the total catch. The most important resource, tunas, represents $63 \%$ of the total catch. The importance of carduma is not only economic, but also ecological and biological. It 
is considered as a total spawner (Maldonado and Remolina, 1976), which means that reproduction is unimodal, and its spawning season occurs in November-December, with a maximum gonadosomatic index (GSI) in the second part of November during normal (non ENSO) years (Zapata, 1992). The main spawning areas are located between Charambirá $\left(4^{\circ} 16^{\prime} \mathrm{N}, 77^{\circ} 32^{\prime} \mathrm{W}\right)$ and Tumaco $\left(1^{\circ} 48.4^{\prime} \mathrm{N}, 78^{\circ} 45.9^{\prime} \mathrm{W}\right)$. The Sanquianga National Park $\left(2^{\circ} 22^{\prime} \mathrm{N}, 78^{\circ} 76^{\prime} \mathrm{W}\right)$ is located between these two localities. The size distribution of total recruited individual fish is between 14.75 and $20 \mathrm{~cm}$ (Zapata et al., 2007) with a maximum size of $20.05 \mathrm{~cm}$ (Zapata, 1992). Historical information of the fishing effort has shown an increase from $3.825 \mathrm{t}$ in 1989 to $31.848 \mathrm{t}$ in 1995 . Between 2000 and 2010, a total catch of $207.957 \mathrm{t}$ was reported $\left(\bar{X}=18905 \mathrm{t} \mathrm{yr}^{-1}\right)$. Beginning in 1993 , a maximum quota regulation of $25000 \mathrm{t} \mathrm{yr}^{-1}$ was implemented (Mojica, 1992). Zapata and Ricci (1997) found the maximum fustainable yield (MSY) for this species to be ca. $30000 \mathrm{t} \mathrm{yr}^{-1}$. This value was implemented as the maximum quota between the years 1998 and 2009. Due to the instability of the governmental agencies in charge of the fisheries management in Colombia (responsibilities have recently changed three times among different agencies), a lack in fisheries and biological monitoring of carduma has been evident. This is critical to the understanding of the population dynamics of this species and to take the appropriate fisheries management measures. To this end, the Ministry of Agriculture and Rural Development financed a project carried out by Harimar S.A., National Parks, Incoder/ICA, Valle University and WWF Colombia, aimed at providing information to evaluate the current status of carduma and to integrate historical landings data in a historical reconstruction of the population dynamics of the species in order to determine the possible effects of El Niño and La Niña events on the fluctuations of its population.

\section{Materials and methods}

Sampling was carried out in two areas of the Colombian Pacific known to harbor large numbers of $C$. mysticetus: the Tortugas Gulf $\left(3^{\circ} 40^{\prime} \mathrm{N}, 77^{\circ} 12^{\prime} \mathrm{W}\right)$ and the Cauca-Nariño marine corridor including the Sanquianga National Park and its buffer zone (Fig. 1). The SST under normal conditions in the coastal zone of the continental shelf ranges between $27.1^{\circ} \mathrm{C}$ and $27.7^{\circ} \mathrm{C}$. From December 2008 to June 2010, monthly monitoring (2-3 days each month) of the fishing operations of the $C$. mysticetus fleet was carried out at the first area (50 hauls). Because of the drastic decrease in catches of the industrial fleet, monitoring conducted between April 2008 and January 2010 in the Cauca-Nariño marine corridor focused on the artisanal fleet (cast nets, 35 hauls). However, at this area it was possible to monitor the commercial fleet in June-August 2008 (29 hauls). For the two areas, the size structure, sex ratio, gonad development, gonadosomatic index (GSI) and hepatosomatic index (HSI) were

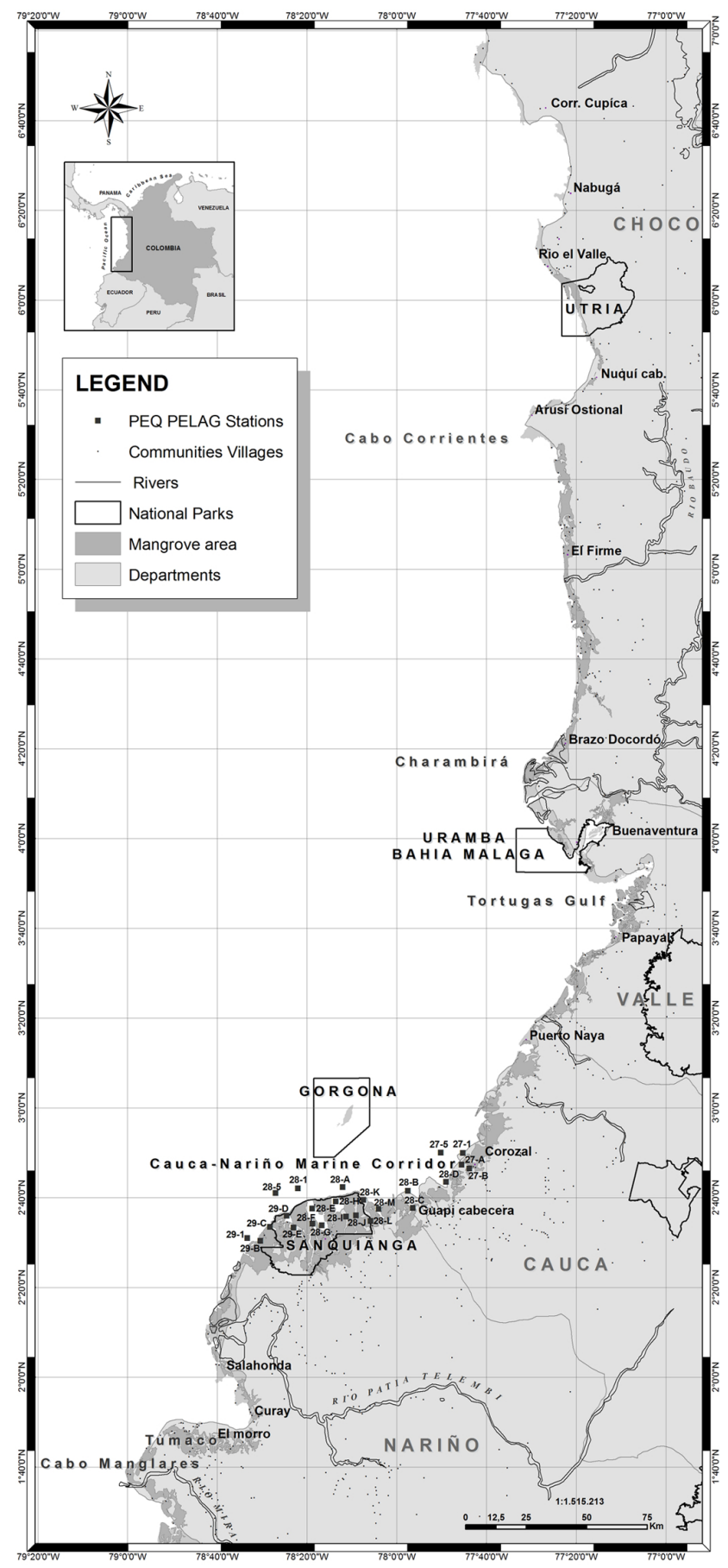

Fig. 1. Study area with two areas of the Colombian Pacific known to harbor large numbers of $C$. mysticetus: the Tortugas Gulf; and the Cauca-Nariño marine corridor; map includes a grid of 24 oceanographic and biologic sampling stations.

calculated based on sub-samples. In addition, zooplankton and icthyoplankton were monitored monthly, between April 2008 and April 2010, in a grid of 24 stations in the CaucaNariño corridor. This area comprises a vast mangrove belt considered a nursery area for fishes, including $C$. mysticetus. 


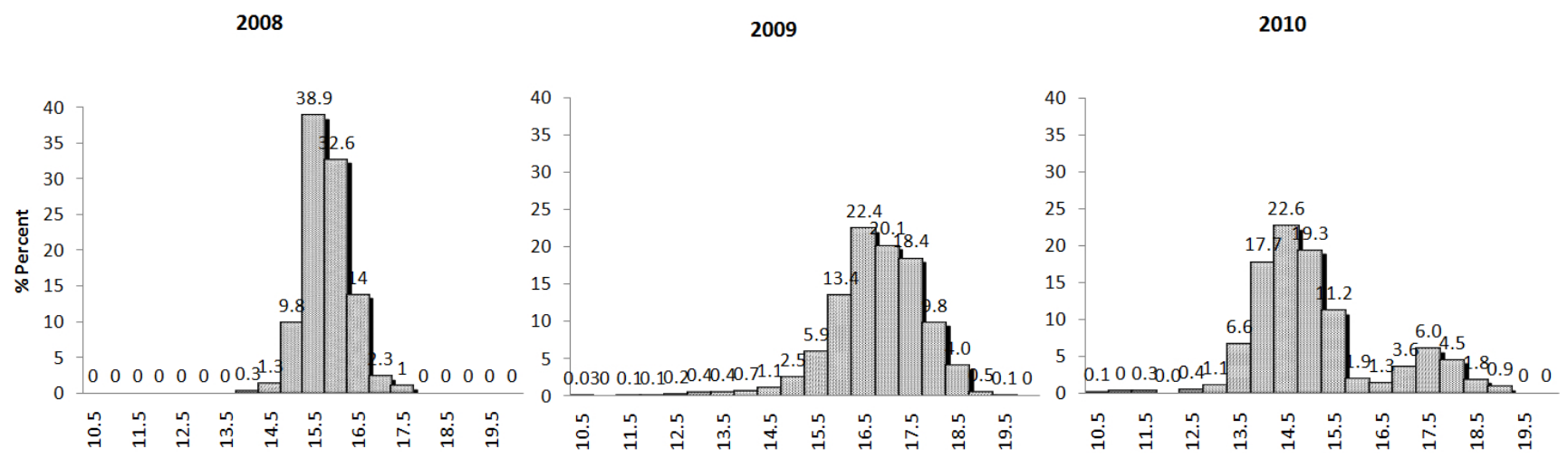

Fig. 2. Catch of carduma (Cetengraulis mysticetus) in percentage of individual fish per size interval, for the industrial fishing fleet at the Tortugas Gulf during 2008, 2009 and 2010.

At each of the 24 stations, temperature and salinity was measured with Hach model Sension 5 equipment. Turbidity was measured with a Secchi disc and zooplankton was collected with a mini-bongo net of $30 \mathrm{~cm}$ diameter at each of its openings, 300 and $500 \mu \mathrm{m}$ mesh size, soft collecting hoses and HydroBios flow meters. Zooplankton biomass $\left(\mathrm{ml} / 1000 \mathrm{~m}^{3}\right)$, the total number of eggs and fish larvae, and the number of eggs and larvae of Engraulidae (standardized to $10 \mathrm{~m}^{2}$ ) were calculated in the laboratory. Time series data of SST in the Pacific Colombian Basin was obtained from the April 2008 to April 2010 NOAA Geostationary Operational Environmental Satellites (http://coastwatch.pfeg.noaa. gov/erddap/info/index.html).

\section{Results and discussion}

Total recruited $C$. mysticetus caught by the purse seine are between 14.75 and $20 \mathrm{~cm}$ and maximum sizes are could be found at $20.05 \mathrm{~cm}$ (Zapata, 1992; Zapata et al., 2007); small size classes were found at the two studied areas. In $2008,1.5 \%$ of the individual fish recorded during the captures made by the industrial fleet in the Tortugas Gulf corresponded to the $10.5-14.5 \mathrm{~cm}$ interval. In 2009 , numbers increase to $3 \%$, while in 2010 a total of $49 \%$ were recorded (Fig. 2). Monitoring of the artisanal fleet carried out in 2008 along the Cauca-Nariño marine corridor showed that $51 \%$ of the individual fish were between $10.5-14.5 \mathrm{~cm}$, whereas in 2009 this size corresponded to $38 \%$ of the individual fish (Fig. 3). In 2010, only small fish were found in January. Sampling of the industrial fleet in the Cauca-Nariño marine corridor did not show a high percentage of small sizes, although catches were very low. The bimodal distribution of the results of monitoring in both areas (the artisanal fleet in the Cauca-Nariño corridor in 2008-2009 and the industrial fleet in Tortugas Gulf in 2010), indicates the presence of two cohorts that may be a consequence of a reproductive disequilibrium in the populations of $C$. mysticetus. The GSI in the Tortugas Gulf had a bi-modal behavior with a peak in October-November 2009 (2.7-2.8) and a second one in January-February 2010 (3.3-2.5, respectively). During December 2008, the GSI was low, indicating a low reproductive activity of $C$. mysticetus. At the Cauca-Nariño corridor, GSI indexes showed reproductive activity between October-December 2008, December 2009 and January 2010 (Fig. 4). At this same area, the mean abundance of Engraulidae eggs (eggs $/ 10 \mathrm{~m}^{2}$ ), was higher in August 2008 (36.3), March 2009 (38.7), June 2009 (33.1) and November 2009 (27.9). Mean larvae abundance (individual fish $/ 10 \mathrm{~m}^{2}$ ) were higher in April (40.1) and November (40.6) 2009. These abundance values are considered to be low, according to the table proposed by Rueda et al. (1992). The proportion of eggs of C. mysticetus for 2008 was $0 \%$ and for 2009 was $0.51 \%$. These data were recorded together with other types of eggs that could represent five species. Nonetheless, the observed proportion of larvae of $C$. mysticetus for the same sampled months varies between $81 \%$ and $97 \%$. The oceanographic conditions in the Pacific Colombian Basin were subject to changes (surface and water column) during 2008-2010. In the first four months of 2008, the whole system showed a recovery from La Niña conditions (increased SST); however, throughout the second semester, SST negative anomalies were detected. These conditions persisted until March 2009 when temperatures reached an extreme value of $25.9^{\circ} \mathrm{C}$ at the Cauca-Nariño corridor. Beginning in 2009, conditions changed abruptly and positive anomalies in SST were detected and continued until April 2010. In fact, the Climatic Alert Bulletin in July 2009 (BAC, 2009) reported the development of El Niño conditions up to the first three months of 2010.

\section{Conclusions}

The period of 2008-2010, dominated by a La Niña-El Niño cycle, was characterized by an abnormal reproductive behavior for C. mysticetus. This abnormal behavior consisted in the partition of the spawning and a reduction of the number 


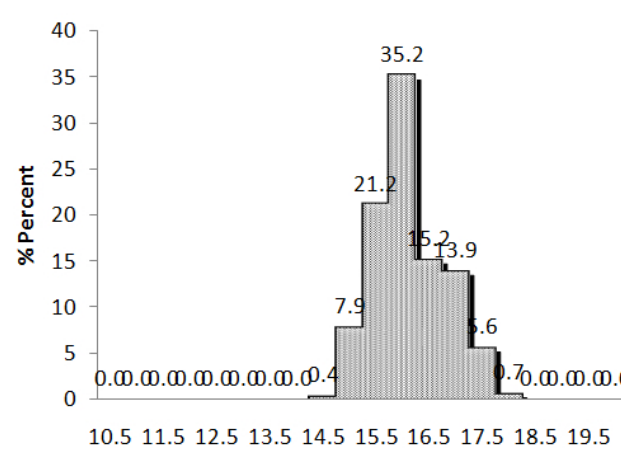

2008

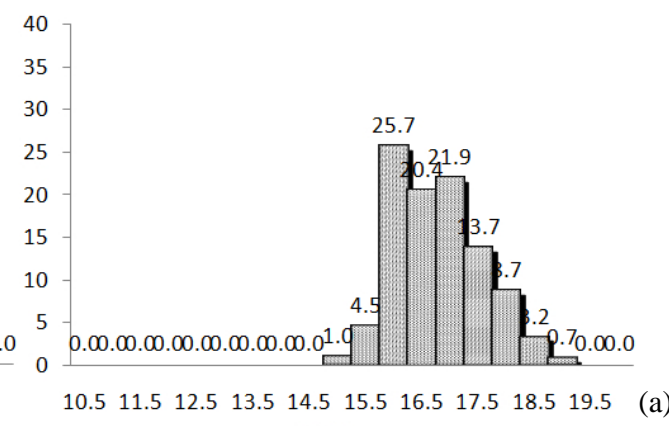

2009
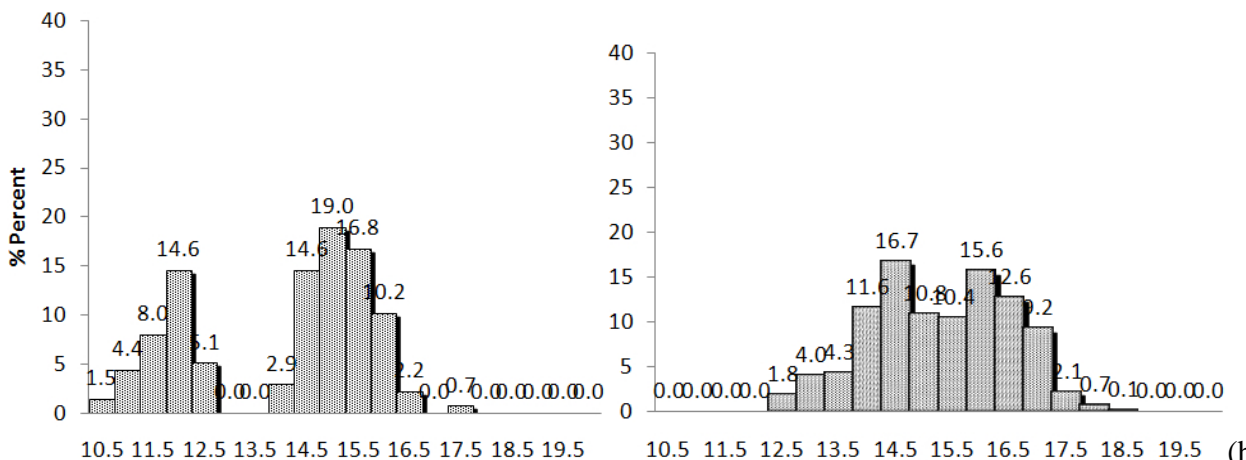

Fig. 3. Catch of carduma (Cetengraulis mysticetus) in percentage of individual fish per size interval in the Cauca-Nariño marine corridor during 2008 and 2009. (a) Industrial fleet. (b) Artisanal fleet.

GSI-HSI "Cauca-Nariño Marine Corridor"

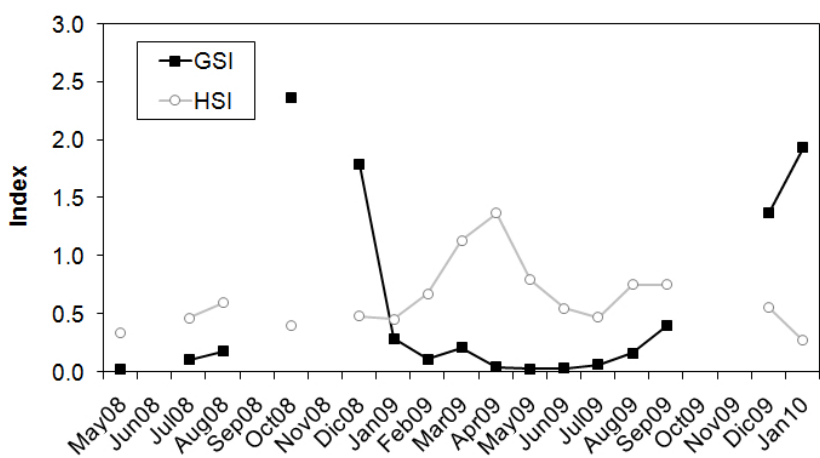

GSI-HSI "Tortugas Gulf"

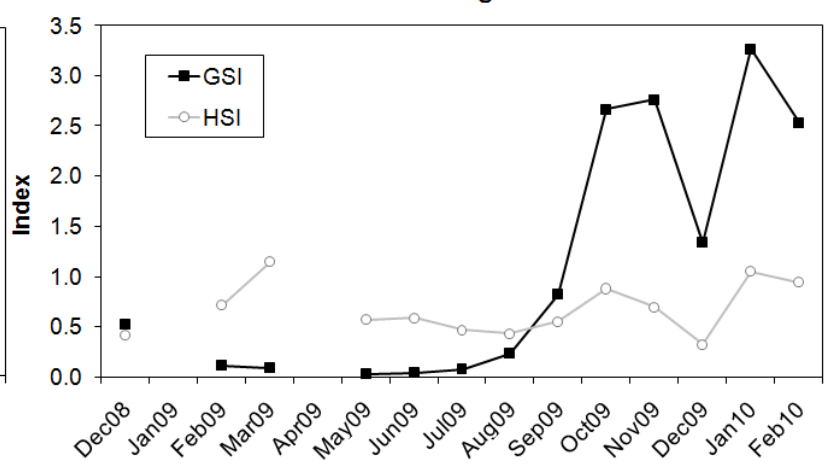

Fig. 4. Gonadosomatic and hepatosomatic indexes of C. mysticetus during 2008-2010 in the Tortugas Gulf and the Cauca-Nariño marine corridor.

of eggs and larvae found in the environment. This may be related to the positive and negative thermal anomalies during this period that finally led to a dramatic reduction in catches. For example, during 2009 and 2010, total catches were 6.969 and $8.252 \mathrm{t}$, respectively, compared to the more than $18.905 \mathrm{t} \mathrm{yr}^{-1}$ average catch for the last decade.

The abnormal oceanographic conditions at both phases of the ENSO phenomenon (warm El Niño and cold La
Niña) can cause disturbances in fish reproduction, producing a mismatch - partitioning and reducing the amount of eggs released to the environment and consequently reducing the number of larvae. In the end, commercial catches of subsequent months may be reduced. Accordingly, BeltránLeón (2002) found that during abnormal oceanographic conditions, a generalized reduction in the reproductive indexes of adults was common. This was explained by fish eating 
less during these conditions, and thus using their hepatic reserves to maintain their metabolic needs and therefore having small and partitioned spawning events. Changes in temperature in the marine environment can further drastically affect fish metabolic systems (Schaefer, 1987), affecting survivorship of eggs and larvae. This is critical to the success or fail of annual cohorts since they depend on the early life stages (Howard and Landa, 1958). If these abnormal conditions are recurrent (i.e. El Niño-La Niña cycles), it is likely that marine populations can be severely affected. For example, in Malaga Bay, located in the central portion of the Colombian Pacific coast (near the Tortugas Gulf), Riascos (2006) found that the El Niño-La Niña cycle of 1997-1998 affected the reproduction of the surf clam Donax dentifer. The main explanatory variables of these reproduction changes were the strong variation in precipitation and salinity within years. During El Niño, a decrease in precipitation caused weak and abnormal spawning events. Growth and somatic production had also negative effects on this surf clam during El Niño.

During earlier El Niño and La Niña events (respectively, 1991-1993, 1997-1998 and 1998-1999), an expansion of the carduma spawning grounds was observed to the north of Charambirá, up to Cabo Corrientes $\left(5^{\circ} 32.3^{\prime} \mathrm{N}, 77^{\circ} 30.6^{\prime} \mathrm{W}\right)$, and a decline in the concentration of larvae was also noticed. This decline was more pronounced immediately after the successive thermal anomalies of El Niño-La Niña that occurred between 1997 and 1999. In 2000, the largest density of carduma larvae was $430 / 10 \mathrm{~m}^{2}$, and in 2001 density further decreased to reach $269 / 10 \mathrm{~m}^{2}$ (Beltrán-León, 2002). Both values are lower than those found in earlier dates by BeltránLeón et al. (1994). In addition to this decline, spawning partition is noteworthy. Zapata (2002) showed the occurrence of this phenomenon for the species towards the end of 1991, during one El Niño event. At the same time, an increase of accompanying fauna and a small vertical migration also occurred. These biological phenomena have also occurred during La Niña events. For instance, in 1999, when one La Niña followed one of the most severe El Niño events yet recorded, the lowest capture rates per unit of effort $\left(27 \mathrm{tday}^{-1}\right)$ occurred, suggesting that this kind of thermal anomaly also has negative impacts on commercial fisheries.

Evidence does not support the statement that population is currently overfished. We consider that optimal levels of exploitation (MSY) of carduma fisheries have been reached $\left(30000 \mathrm{t} \mathrm{yr}^{-1}\right)$, but given the low relative abundance of the species, it is important to continue the implementation of cautionary measures aimed at the sustainable exploitation of this valuable resource, especially when thermal anomalies affect local population of the species in Colombian coastal waters. These measures include a fishing ban during the breeding season, limited fishing quotas, limited increase in the number of fishing vessels, and more importantly, maintaining a permanent biological monitoring of the populations in the breeding areas, coupled with systematic recording of oceanographic variables. The recent adjustments of the fishing quota for this resource made by the Colombian Ministry of Agriculture and Rural Development to $27000 \mathrm{t}$ for 2010 and to 25000 for 2011 based on the results of the biological monitoring carried out between 2008 and 2010 are a clear demonstration of the importance of this approach.

Acknowledgements. These results are derived from the project "Evaluation of the current state by small pelagic fisheries to ensure the sustainability of the resource in the Pacific and strengthen the Colombian fishing industry" (Code: 2007T6301-333-795/2007), co-funded by the Ministerio de Agricultura y Desarrollo Rural (agreement 05/07 IICA-MADR). The authors would like to thank WWF Colombia, Harinas y aceites de pescado de mar - HARIMAR S.A., Unidad Administrativa Especial del Sistema de Parques Nacionales Naturales - UAESPNN, Universidad del Valle, Instituto Colombiano Agropecuario - ICA, Instituto Colombiano de Desarrollo Rural-Incoder and Ministerio de Agricultura y Desarrollo Rural.

\section{References}

BAC: Boletín de Alerta Climático de Diciembre de 2009, No 231: Comisión Permanente del Pacífico Sur, Secretaría General, Guayaquil, Ecuador, 14 pp., 2009.

Beltrán-León, B. S: Changes in the distribution, abundance and spawning season of the anchovy Cetengraulis mysticetus, in the Pacific ocean off Colombia during the events of El Niño and La Niña, Invest. Mar, 30, 106-107, 2002.

Beltrán-León, B. S., Ramos, G., Escobar J. C., and Tovar J.: Distribución y abundancia de huevos y larvas de Opisthonema spp. (Gill, 1861) y Cetengraulis mysticetus (Gunther, 1866) (Pisces: Clupeiformes) en el Pacífico colombiano durante enero de 1993, Bol. Cient. INPA, 2, 181-199, 1994.

Howard, G. V. and Landa, A.: A study of the age, growth, sexual maturity and spawning of the anchoveta (Cetengraulis mysticetus) in the Gulf of Panama, Bol. CIAT, 2, 371-467, 1958.

Maldonado, J. and Remolina, R.: Contribución al conocimiento de la biología y las pesquerías de Anchoveta colombiana Cetengraulis mysticetus (Gunther), in: Memorias sobre el Océano Pacífico Sudamericano, edited by: Vélez, V. and Beltrán, R., Tomo I. Cali, 275-318, 1976.

Mojica, H. O: La pesquería de Pequeños Pelágicos en el Pacífico colombiano, Ministerio Agricultura, Instituto Nacional de Pesca y Acuicultura - INPA, Santa Fé de Bogotá, 22 pp., 1992.

Riascos, J. M.: Effects of El Niño-Southern oscillation on the population dynamics of the tropical bivalve Donax dentifer from Málaga bay, Colombian Pacific, Mar. Biol., 148, 1283-1293, doi:10.1007/s00227-005-0165-4, 2006.

Rueda, C., Beltrán-León, B., Velasco, A., and Delgado, F.: Ictioplancton de las familias Clupeidae y Engraulididae en el Pacífico colombiano Cruceros PEC/PELAG 1991, Informe técnico Programa Regional de Cooperación Técnica para la Pesca CEEPEC, Buenaventura, 76 pp., 1992.

Schaefer, K. M.: Reproductive biology of the black skipjack, Euthynnus lineatus, an Eastern Pacific tuna, Inter.-Am. Trop. Tuna Comm. Bull., 19, 169-260, 1987.

Zapata, L. A.: Contribución al conocimiento de la biología, hábitos alimenticios y crecimiento en la carduma Cetengraulis 
mysticetus (Gunther, 1866) en el Pacífico colombiano, Tesis de Grado, Universidad del Valle, Sección Biología Marina, Cali, 127 pp., 1992.

Zapata, L. A.: Effects of El Niño and La Niña on the fisheries of the Colombian Pacific, Invest. Mar, 30, 205-206, 2002.

Zapata, L. A. and Ricci, O. L.: Resultados de la evaluación del recurso carduma en el Pacífico colombiano 1991-1997, Informe Técnico INPA, Buenaventura, 23 pp., 1997.
Zapata, L. A., Peña, E. J., and Rubio, E. A.: La pesquería de pequeños pelágicos en el Pacífico de Colombia: 373-403, in: Capacidad de pesca y manejo pesquero en América Latina y el Caribe, edited by: Agüero, M., FAO Documento Técnico de Pesca, No. 461, Roma, 403 pp., 2007. 